\title{
Tömeges digitalizálás az egyházi levéltárakban - megfigyelések, következtetések
}

\section{Bevezető}

2018 őszén egy kérdőívvel kerestük meg az egyházi levéltárakat, hogy a tömeges digitalizálás tapasztalatairól tájékozódjunk. A felmérés egy konferencia alkalmából készült a Magyar Felsőoktatási Levéltári Szövetség (MFLSZ) 2018. évi vándorgyülésére, a továbbiakban olvasható írásunk az előadás vázlatának átdogozott változata. ${ }^{1}$

A címben jelzett témával kapcsolatban az első tisztázandó kérdés, hogy mit értsünk tömeges digitalizálás alatt, vagyis milyen esetekben tekintettük „tömegesnek" a levéltári digitalizálós tevékenységet. A kitöltött kérdőívek alapján gyorsan megállapítható volt, hogy a képi digitalizálás valóban hangsúlyossá vált, és joggal nevezhetö tömegesnek intézményeinkben, ugyanis több mint 6,3 millió (!) digitális képről számoltak be a válaszadók - elsősorban ennek felmérésére, vizsgálatára törekedtünk. Figyelembe véve a kapott válaszokat, és tekintettel az egyházi levéltárakra jellemző néhány személyes, kis intézményi méretekre, a képfelvételek számát illetően végül 50 ezernél húztunk határt: az ilyen nagyságrendü, illetve ezt meghaladó képállományról beszámoló jelentéseket értékeltük tömegesként. A következőkben ezek válaszait összesítjük, elemezzük. A tömeges digitalizálás egy másik fontos jellemzője volt számunkra a mennyiségen túl, hogy a levéltáros által tervezett, módszeres és rendszeres tevékenységet feltételez, vagyis nem merül ki az ad hoc kutatói igények, megrendelések kielégítésében, és az így készült másolatok gyüjtésében.

\section{Hol rendelkeznek nagyobb képállományokkal?}

A kapott válaszok alapján megállapítható, hogy tömeges digitalizáló tevékenység az egyházi levéltárak kb. felében folyik. A nagyobb képállománnyal rendelkező levéltárak - 16 intézmény és egy, több levéltárat érintő, közös projekt - felekezeti csoportosításban a következők:

- 3 evangélikus: Őskereső-projekt, Evangélikus Országos Levéltár (EOL), Soproni Egyházközség Levéltára

${ }^{1}$ A 2018. szeptember 14-én elhangzott előadás szerkesztett változatának másik közlése: Tömeges digitalizálás az egyházi levéltárakban - megfigyelések egy kérdőíves felmérés alapján. = Levéltári Szemle, 69. évf. 2019. 2. sz. 20-31. p. 
- 3 református: Tiszántúli Református Egyházkerületi és Kollégiumi Levéltár (Debrecen), Dunamelléki Református Egyházkerület Ráday Levéltára (Budapest), Baranyai Református Egyházmegye Levéltára (Pécs)

- 11 római katolikus (8 egyházmegyés és 3 szerzetesi): Győri Egyházmegyei Levéltár, Gyulafehérvári Főegyházmegyei Levéltár, Kalocsai Főegyházmegyei Levéltár, Pécsi Egyházmegyei Levéltár, Prímási Levéltár (Esztergom), Székesfehérvári Püspöki és Székeskáptalani Levéltár, Váci Püspöki és Káptalani Levéltár, Veszprémi Főegyházmegyei Levéltár, Jézus Társasága Magyarországi Rendtartomány Levéltára (Budapest), Pannonhalmi Főapátsági Levéltár, Piarista Rend Magyar Tartománya Központi Levéltára (Budapest).

A képállomány zöme, 5,2 millió kép (a felvételek 83\%-a) hat helyen készült, és közel 1,1 millió kép (17\%) található még további tizenegy intézményben. A felvételszámok tekintetében meghatározó hat intézmény közül két esetben több egymilliónál a képfelvételek száma, és négy másik levéltárban haladja meg a képszám a félmilliós nagyságrendet (Kalocsai Főegyházmegyei Levéltár 1,5 millió, Öskereső-projekt 1,2 millió, Pécsi Egyházmegyei Levéltár 710 ezer, Váci Püspöki és Káptalani Levéltár 681 ezer, Tiszántúli Református Egyházkerületi és Kollégiumi Levéltár 578 ezer, Győri Egyházmegyei Levéltár 550 ezer).

\section{Milyen forrásokról készülttek a digitális képmásolatok?}

2018 őszén összesen 6,3 millió képfelvételről számoltak be a levéltárak, melyek tematikus megoszlását a következő táblázatban foglaltuk össze. ${ }^{2}$

\begin{tabular}{|l|l|l|}
\hline \multicolumn{1}{|c|}{ A képfelvételek tematikája } & \multicolumn{1}{|c|}{$\begin{array}{c}\text { Az összes } \\
\text { adatszolgáltató } \\
\text { levéltárban }\end{array}$} & $\begin{array}{c}\text { A felvételszámokban } \\
\text { kiemelkedő hat intézményben }\end{array}$ \\
\hline anyakönyvi jellegü & 4,7 millió $(75 \%)$ & 3,9 millió $(84 \%)$ \\
\hline helytörténet, egyházközségek & 645 ezer $(10 \%)$ & 482 ezer $(75 \%)$ \\
\hline segédletek (iktatók, mutatók) & 363 ezer $(5,7 \%)$ & 336 ezer $(93 \%)$ \\
\hline egyéb levéltári forrás & 585 ezer $(9,3 \%)$ & 473 ezer $(81 \%)$ \\
\hline összes képfelvétel & 6,3 millió $(100 \%)$ & 5,2 millió $(83 \%)$ \\
\hline
\end{tabular}

1. táblázat. A képfelvételek tematikus megoszlása

${ }^{2}$ A táblázat második oszlopában a témánkénti felvételszámok, illetve azok százalékos aránya szerepel az összes felvételhez képest, a harmadik oszlopban pedig a fentebb említett, kiemelkedő felvételszámú hat intézmény témánkénti képfelvételeinek száma, illetve az egyes témákon belül képviselt, százalékos felvételszám-aránya található. 
A számokból jól látható az anyakönyvi jellegü források meghatározó többsége (75\%), melynek hátterében nyilvánvalóan az intenzív családkutatói érdeklődés, $\mathrm{s}$ az ehhez kapcsolódó e-kutatói szolgáltatások állnak. Második helyen (10\%-kal), jóval kisebb nagyságrendben, de mégis jelentős felvételszámmal a helytörténet áll, a képfelvételek itt nagy részben (73\%-os arányban) négy olyan intézményhez köthetők, ahol jellemző törekvés az iratmentés (Debrecen, Győr, Kalocsa, Pécs). Ez föként a plébániák, gyülekezetek látogatását-felmérését, digitális másolatok készítését, illetve bizonyos esetekben az iratok beszállítását jelenti, sőt időnként hungarica jellegü másolatgyüjtés is előfordul a határon túlra került egyházközségeknél. A harmadik jól elkülöníthető csoport (közel 6\%-os részesedéssel) az irattári segédletek (iktatók, mutatók) világa, a levéltárak többségénél - 17-ből 10 adatszolgáltatónál - törekednek hasonló források digitalizálására. A cél itt elsősorban a kutatók tájékozódásának segítése, időnként online elérhetőség biztosításával. Az utolsó, egyéb kategória részleteiről, pontos összetételéről nincsenek adataink, de a kapott válaszok megjegyzései alapján feltételezhető, hogy a több mint félmilliós felvételszám (9\%) mögött föként protokollumok, azaz különféle testületi jegyzőkönyvek és gyüjteményes jellegü levéltári dokumentumok (oklevelek, térképek, tervrajzok, fotók) állnak. A részben ide sorolt egyházlátogatási (vizitációs) jegyzőkönyvek számítása kérdéses lehet, és változó eredményt hozhat: egy részüket ugyanis a helytörténet témájánál tüntették fel az intézmények, s ha mindenütt így tennénk, az 1-2\%-kal erősíthetné a helytörténet arányát az egyéb kategória csökkenése mellett.

A táblázatból az is látható, hogy a felvételszámok tekintetében kiemelkedő hat intézmény aktivitása valamennyi témában igen jelentős. A csúcsértéket a 93\%os részesedés jelenti a segédleteknél, második helyen az anyakönyvek $84 \%$-os aránya áll. Bár abszolút értékben más nagyságrendủ számok vannak az említett témák mögött, mégis megállapítható, hogy a nagyobb ütemben digitalizáló intézmények az anyakönyvek mellett viszonylag hamar hozzáláttak az iktatók-mutatók fényképezéséhez, és eredményesek voltak a levéltári segédletek feldolgozásában is.

\section{Mióta digitalizálnak az egyházi levéltárak?}

Tömeges digitalizálásról (digitalizáló mühelyek müködéséről) az egyházi levéltárakban nagyjából tíz éve beszélhetünk, a folyamat kezdetei kb. 2009-re tehetők. ${ }^{3}$ A létrehozott képanyag segítségével az első internetes e-kutatás 2010 decemberében indult Kalocsán, melyet aztán további hasonló szolgáltatások is

\footnotetext{
${ }^{3}$ A munka megkezdésére hatással volt „Az egyházi anyakönyvek digitalizálásának lehetőségei - módszertani tanulmány”, amely az NKA Levéltári Szakmai Kollégiuma megbízásából, 2008ban született (szerzői Biszak Sándor, Lakatos Andor és Vajk Ádám), és pdf-változatban a Magyar Levéltáros Egyesület (MLE) honlapján kapott helyet. Az 57 oldalas tanulmány számba vette az anyakönyvek tömeges feldolgozásának módjait, a kutatói szolgáltatások lehetőségeit, a kapcsolódó technikai feltételeket és költségeket. A tanulmány szövege a régi webhelyen (http://www.leveltaros.
} 
követtek (Gyulafehérvár 2012, Győr 2013, Vác 2014, Öskereső 2015, Veszprém 2016, Jezsuita Lt. 2016, Pannonhalma 2017, Pécs 2018). Az első években még csak néhány helyen dolgoztak, a terjedés fordulópontjának a 2014-es év tekinthető, a mostani felmérésben szereplő levéltárak többségében, tizenegy helyen (65\%) ezt követően láttak munkához.

Nem meglepő ezek után, hogy az eredmények (felvételszámok) zöme is az utóbbi négy évhez köthető. Az éves gyarapodás ebben az időszakban 14 válaszadó intézmény átlaga alapján levéltáranként 80 ezer felvétel/év volt, és ez összességében évente több mint egymillió új képet jelentett. Kiemelkedő teljesítményt az Öskereső projekt produkált (300 ezer képfelvétel/év gyarapodással), de az átlagos növekedést jelentősen meghaladó eredményt ért el még két további levéltár, Kalocsa és Pécs, 200-200 ezer felvétel/év értékkel.

\section{Hogyan készültek a felvételek?}

A válaszadó intézmények általában rendelkeznek a digitális képek tömeges készítéséhez szükséges műhelyekkel, gyakran több digitalizáló állomás (szkennerek, fényképezőgépek, világító eszközök, állványzat és számítógépek együttesének) párhuzamos múködéséről is beszámoltak. A mühelyek elterjedésének köszönhető, hogy a képfelvételek több mint $90 \%$-a a levéltárak saját eszközeivel, a forrásokat őrző-kezelő intézményekben készült. A többi kép főként külsős munkákból (pl. Arcanum, Monasterium), illetve kisebb részben más levéltáraktól átvett digitális másolatokból ered (pl. MNL anyakönyvi mikrofilmmásolatai a Ráday Levéltárban). A külsős munkák időben gyakran megelőzték a levéltári mühelyek létrejöttét, és főként egyedi, speciális elbánást igénylő források (pl. térképek, oklevelek) esetében fordultak elő.

A 6,3 millió dokumentum kb. 75\%-a digitális fotó, 25\%-a szkennelt kép. A fotók túlsúlya részben összefügghet a munkafolyamatok átlagos sebességével, a fényképezéssel ugyanis általában a kutatói célú másolatok minél gyorsabb elöállítására törekedtek. A digitális fényképezés terjedését segítette az is, hogy az elmúlt évtizedben a levéltári digitalizálásra alkalmas fotós mühelyek felszerelése (jó felbontású, 12 megapixel feletti, tükörreflexes fényképezőgép, speciális objektív, világítás, állványzat, számítógépes fényképező szoftver) az intézmények számára elérhetővé - hozzávetőleg félmillió forintból beszerezhetővé - vált. A szkennelt képek esetében az általában lassabb tempójú levéltári feldolgozás jobb képminőséggel párosult, viszont A3-as méret felett nagyobb értékű (több millió forintos) eszközöket igényelt, terjedésének így részben a magasabb költségek szabtak határt. Az egyes esetekben szükséges, ideális technikai megoldásról valójában a források méretének-jellegének megfelelően lehet jól dönteni, de a helyi

hu/akvi_tanulmany.pdf) már nem érhető el, jelenlegi elérhetősége: https://archivum.asztrik.hu/ sites/default/files/letoltesek/akvi_tanulmany.pdf (2019. január 3.) 
technikai adottságok függvényében mégis jellemző, hogy vannak intézmények, ahol kifejezetten az egyik vagy a másik megoldást részesítik előnyben.

A különféle eszközökkel létrehozott képfájlok átlagos mérete 5-10 MB, az általánosan elterjedt képformátum a JPG. Kis mennyiségben TIFF formátumú állományok is előfordulnak, de ezek generálását - és föként tárolását - tömeges mennyiségben általában nem vállalják az intézmények. A használatban lévő (szerkesztett, módosított) képek átlagos mérete 1-5 MB között mozog, az online szolgáltatói verziók inkább csak 1-2 MB közöttiek (néhány éve még 1 MB alatti terjedelemre törekedtek), míg az intézmény számára archivált (teljes méretü, vízjelezett, részben tömörített) példányok 2-5 MB körüliek.

A képeket előállító, kezelő humánerőforrás-igényről jellemző adat, hogy a felvételek 70\%-ának eredete technikus munkatársakhoz köthető, és csak 30\%-ot készítettek levéltárosok. Hat intézményből jelezték, hogy kedvezményes foglalkoztatási lehetőségekkel is éltek (közmunkaprogram, rehabilitációs pályázatok, fiatal munkakezdők támogatása stb.). A képek mennyiségét tekintve tehát a technikus munkatársak váltak meghatározóvá a képi digitalizálásban (akiket a feladatra betanítva általában meghatározott időszakra, változó időkeretek és körülmények között alkalmaznak), de vannak olyan intézmények, ahol fontosnak tartják, hogy levéltáros munkatárs digitalizáljon, és eszerint szeretnének eljárni a jövőben is. Részben ez utóbbi szemlélet, részben a digitalizálás folyamatával együtt járó egyéb levéltáros teendők magyarázzák, hogy a feladat az elmúlt években több helyen adott hivatkozási alapot a létszámfejlesztésekhez. Az egyházi levéltárak az elmúlt öt évben a korábban jellemző 1-2 fösből átlagosan 2-3 fös intézmények lettek. A gyarapodás nyilván nem csak ennek köszönhető, de minden bizonnyal van összefüggés.

A képi digitalizálásra fordított átlagos munkaóraszámot nehéz meghatározni, de ahol rendelkezésre áll mühely és digitalizáló munkatárs, ott minimum napi 4 , de inkább 8 órás üzemre törekednek. Jellemző összefüggés, hogy 8 óra képi digitalizálás kapcsán általában 2-3 óra levéltáros szakmai tevékenységet jeleztek (előkészítés, adminisztráció, ellenőrzés, kapcsolódó kutatószolgálati teendők stb.). Összességében megállapítható, hogy a képi digitalizálással járó feladatok rendszeres szakmai teendőket eredményeztek a levéltárosok számára, és a kapott válaszok becsült értékei alapján átlagosan napi két munkaórát igényelnek.

\section{Milyen célból digitalizáltak a levéltárak?}

A válaszadók a digitális képfelvételek nagy többségét, 88\%-át kutathatónak minősítették, de ezen belül változóak az állomány hozzáférésének lehetőségei. Az interneten, teljesen szabadon csak a képek kb. 5\%-a érhető el, a tartalom zöme, mintegy $80 \%$-a regisztrált felhasználók (a levéltárakban nyilvántartott e-kutatók) 
számára hozzáférhető az intézmények honlapján, s a kutatható állomány kisebb része, kb. 15\%-a csak helyben, a levéltárak kutatótermeiben használható.

A digitalizálás célja tehát elsősorban a kutatószolgálat fejlesztése volt, melynek során az egyházi levéltárak többségükben online szolgáltatások kiépítésére törekedtek, regisztrált kutatóforgalommal. A helyben történő (offline) e-kutatás lehetőségének biztosítását - az intézmények hagyományos kutatószolgálatának részeként - elsősorban állományvédelmi szempontok motiválták.

A válaszokból az is jól látható, hogy a tömeges digitalizálás tömeges kutatási lehetőségeket is eredményezett. A nagyobb online kutatói szolgáltatásoknál a kutatási esetek száma ugyanis jelentős mértékben, a korábbi forgalom 10-50-szeresére nőtt (vagyis a növekedés minimum értéke 10-szeres, a maximum 50-szeres volt). A jellemző éves e-kutatási esetszámok, felhasználói belépések öt nagyobb szolgáltató esetében: Öskereső 39 ezer, Kalocsa 13 ezer, Pécs 12 ezer, Vác 9 ezer, Győr 7 ezer eset. A helyi hozzáférés - kutatószobában történő böngészés - esetén a kutatási esetszámok szerény mértékben növekedtek, de nagyságrendileg nem változtak.

Az online hozzáféréssel tehát jelentősen megnőtt a kutatások intenzitása (a kutatási alkalmak és a megtekintett képek-oldalak száma egyaránt), és az e-kutatók átlagosan több időt fordítottak munkájukra, legtöbbször az esti órákat, hétvégéket is hasznosítva.

Az egy-egy intézményben, naponta megtekintett több ezer képet figyelembe véve megállapítható, hogy az eredeti források mozgatása hasonló nagyságrendben nem csupán jóval több időt igényelne, de sokszor fizikailag is lehetetlen volna (férőhelyek, illetve levéltáros kapacitás hiányában), és az intenzív kutatásnak az állományvédelmi szempontok is szükségszerüen határt szabnának. Az internetes e-kutatás szolgáltatás ugyanakkor alkalmasnak bizonyult a tömeges kutatói igények kielégítésére.

Az e-kutatói regisztráció általában díjköteles az egyházi levéltárakban. Ezt időnként bírálják levéltáros és kutatói körökben egyaránt, mintegy számonkérve a levéltári kutatások ingyenességének alapelvét. Ebben a kérdésben véleményünk szerint érdemes figyelembe vennünk a szolgáltató intézmények jellegét, melyek jogi meghatározással élve: nyilvános magánlevéltárak. Működési kereteik, lehetőségeik, fenntartói viszonyaik szükségszerúen eltérnek a közlevéltárak világától, szolgáltatásaik pedig gyakran túlmutatnak a központi raktárak állományain, a digitális tartalom sokoldalú tevékenység (gyüjtőmunka, rendszerezés, utazás, beszállítások stb.) eredménye. A hasonló szolgáltatások létrehozásához általában nem álltak rendelkezésre a feladatok nagyságával arányos erőforrások és céltámogatások. A néhány fős, kis intézmények sokszor erőn felül teljesítettek, amikor a pénzhiányt befektetett munkával (házilagos, egyszerü, olcsó megoldásokkal), összefogással, partnerek és támogatók keresésével stb. igyekeztek orvosolni. 
A digitalizáló projektek költségvetésében kétségtelenül volt (és ma is van) szerepe a regisztrációs díjaknak, melyek révén a kutatók is hatékony részeseivé váltak a szolgáltatások felépítésének, müködtetésének és bővítésének. A kutatók számára az e-kutatás általában olcsóbb a hagyományos, helyben történő kutatásoknál (a szükségszerü utazásokat, kapcsolódó egyéb kiadásokat, munkaidő-kiesést stb. figyelembe véve mindenképpen), s az intenzív online kutatási lehetőségekkel együtt, a közös cél (forrásokban gazdag, jó minőségủ szolgáltatások) támogatásának tudatában mindez - tapasztalataink szerint - általában kutatói elégedettséget eredményezett. A szolgáltató intézmények törekedtek arra, hogy az e-kutatás minél szélesebb rétegek számára elérhető maradjon, vagyis a díjszabás ne legyen akadálya a kutatásoknak. A regisztrációs díjak alkalmazásában, rendszerében pedig minden bizonnyal lesznek, illetve már jelenleg is vannak változások, továbbá a jövőben is várhatók ingyenesen múködő szolgáltatások. A kutatói regisztrációt viszont általában még az utóbbiak esetében is megkívánják az egyházi levéltárak (a helyben történő kutatásokhoz hasonlóan), ez közvetlenebb kapcsolattartást eredményez és alaposabb kutatói statisztikák készítését is lehetővé teszi.

\section{Mi történt velünk?}

Immár a kérdőíven túl vetjük fel ezt az összegző kérdést, véleményünk szerint jogosan, hiszen a tömeges digitalizálás az elmúlt néhány évben az egyházi levéltárak hétköznapjainak is részévé vált, új feladatokkal és rendszeres teendőkkel formálva életünket. Erre a munkára levéltárainkat jogszabály nem kötelezte, elsősorban a kutatói igényeket vettük figyelembe (mely főként a családkutatók részéről volt érezhető), hozzátéve a magunk levéltáros állományvédelmi szempontjait és az iratmentés, illetve dokumentumgyüjtés lehetóségét (l. egyházi anyakönyvek és helytörténet témájának kapcsolását, dominanciáját a digitalizált források körében).

A tömegessé váló online kutatások időközben új alapokra helyeződtek, jóval intenzívebbé váltak kutatói kapcsolataink. Tíz éve még általában túlzónak tartottuk az olyan kutatói igényeket-kéréseket, hogy forrásainkat az interneten, otthonról használhassák, mára mindez lehetségessé, sőt megszokottá vált az e-kutatást biztosító levéltárak körében. Az új szolgáltatásokat a kutatók szívesen fogadták, és a regisztrációs díjak befizetésén felül is támogatták azok fejlesztését és fenntartását. Túlfizetések és különféle anyagi felajánlások (pl. bizonyos források digitalizálásával kapcsolatos céltámogatások) is előfordultak, de ezen túl a szakmai együttmüködés lehetőségei, a kutatókkal kialakult kapcsolatok is fontosak voltak (alkalmat adva információk, kutatási eredmények megosztására, egymástól távol élő személyek közös munkájára stb.). Az erkölcsi elismerés egyik példája az Év Kutatóhelye-díjak adományozása a Magyar Családtörténet-kutató Egyesület (MACSE) részéről a szolgáltató egyházi levéltárak számára (Kalocsa 2011, Orosházi Evangélikus Gyülekezet Levéltára 2014, Vác 2015). 
Az e-kutatás lehetősége nem merül ki a tömeges kutatói igények keresésében és kielégítésében, a létrejött mühelyek, a kialakult technológiai és módszertani megoldások jó lehetőséget adnak a levéltárosok számára más, aktuálisnak vélt és feltárásra érdemes források digitalizálására is, segítve azok megismerését és feldolgozását. A családkutató-központú szolgáltatásokkal olyan müködő modellekhez jutottak levéltáraink, melyek tapasztalatait és erőforrásait sokoldalúan, akár szélesebb körben is alkalmazhatják.

Pozitívumként értékeljük, hogy a tömeges digitalizálás intézményeink saját hatáskörében maradt, vagyis általában a levéltárosok irányításával és hatékony közremüködésével folyik, biztosítva a szakmai követelmények érvényesülését. Ahhoz, hogy ez így maradhasson, informatikai és technológiai tudásunk folyamatos fejlesztésére van szükség, ami komoly erőfeszítéseket és összefogást kíván kis levéltáraink részéről.

A folyamat tehát kiváló alkalmat ad a szakmai együttmüködésre, nem véletlen, hogy konferenciáink visszatérö témája lett. A rendszeres találkozókhoz és eszmecserékhez, a tapasztalatok megosztásához a Magyarországi Egyházi Levéltárosok Egyesülete (MELTE) biztosít számunkra keretet és jó lehetőségeket, míg az egyesület a megfelelő információs környezet (módszertani ismeretek, felhasználható modulok, szoftveres megoldások) biztosításával, illetve közös adatbázisok és tartalomszolgáltatások indításával (Arca, Matricula) tudja segíteni az egyes intézmények munkáját. Az elkövetkező években ezek fejlesztése várhatóan hangsúlyos tevékenység lesz a MELTE életében, összehangolva az e-kutatói szolgáltatások tartalmát és a levéltári segédletek adatbázisát. Az összefogást egyébként az anyagi-technikai szempontok szinte szükségszerúen hozták létre, így előfordul például, hogy öt-hat levéltári szolgáltatás egy közösen fenntartott szerveren üzemel.

Manapság már nem csak a kutatók számára fontos a levéltári digitalizálás, az intézmények fenntartóinak is vannak ezzel kapcsolatos elvárásai (pl. biztonsági másolatok létrehozása, vagy információk gyorsabb elérhetősége, hatékonyabb kezelése érdekében). A tömegessé váló digitalizálás tehát, úgy tünik, szinte elkerülhetetlen, a folyamat valószínúleg erösödni fog. Nem véletlenül jegyezte meg egy kollégánk a kérdőíven, hogy bármit is tegyünk, „a képek száma nő, mint tengerben a müanyag". Némiképpen finomítva a megállapítás élét, mi inkább tengernyi képet emlegetnénk, s egy ókori latin közmondással folytatnánk: „Navigare necesse est” - mert hajóznunk valóban egyre inkább szükséges ezen a tengeren, a kényszer régen is megvolt, és most is adott. De az elmúlt évtized tapasztalatai - véleményünk szerint - azt mutatják, rajtunk is múlik, hogy ez csupán a korjellemző, vagy új utakkal, szakmai eredményekkel is kecsegtetö lehetőség. 


\section{Befejezés helyett: mi várható a jövőben?}

Írásunk egy általános, első megközelítés a témával kapcsolatban, gyorsan változó körülmények közepette. Szinte biztosra vehető, hogy az említett számadatok a megjelenés idejére elavulnak, hiszen a felmérés egyik tanulsága, hogy manapság akár néhány hónap alatt is képek százezrei születnek. Megfigyeléseinkkel elsősorban a nagyságrendekre, a jellemző folyamatokra, kapcsolódó jelenségekre és lehetőségekre kívántuk felhívni a figyelmet, a részleteket tekintve természetesen még sok-sok szakmai, módszertani és technikai kérdés felvethetö. Bízunk benne, hogy a jövőben erre is sor kerülhet majd. Az alaposabb vizsgálatokhoz további tájékozódásra, adatgyüjtésre van szükség, és nagyon hasznos lenne, ha az egyes digitalizáló projektekről és szolgáltatásokról külön ismertetők is készülnének, a tevékenység folyamatának, eredményeinek és tapasztalatainak részletes összefoglalásával.

Mi várható a jövőben? Gyakran teszik fel a kérdést kutatók és levéltárosok egyaránt. Visszatérve fentebbi tenger hasonlatunkhoz (Navigare necesse est), az időjárást, vagyis a körülményeket hosszabb távon előre jelezni nyilván nem lehetséges, de bizonyos áramlatok, folyamatok mégis érezhetők, felismerhetők. Véleményünk szerint az egyik ilyen jelenség, hogy a tömeges feldolgozás előbbutóbb párhuzamos szolgáltatásokat eredményez. Bizonyos forrástípusok, de akár konkrét források is több helyen, több változatban is előfordulhatnak (talán elég az anyakönyvi-családtörténeti tartalmak sokféle, sok helyen történő internetes megjelenésére utalnunk), s ez a folyamat túlmutat az egyházi levéltárak körén, sőt általában a levéltárak világán is. Ebben a helyzetben egy-egy intézmény mindenképpen csak valamilyen töredéket, részletet tud adni, s ennek az összetettségnek tudatában, körültekintően kell a munkánkat tervezni, valamint egyedi információink elhelyezésére és elérhetőségére megfelelő megoldást találni.

A hajók időnként flottákba tömörülnek, ami nálunk is kézenfekvő módon segíthet az imént említett töredezettségen - de ez az együttmüködés természetesen sokféle módon, több szinten történhet. Egy felekezet országos összefogásának szép példája az evangélikus Őskereső projekt és kutatói szolgáltatás. ${ }^{4}$ A MELTE több felekezet, valamennyi egyházi levéltár számára biztosít közös e-kutatói felületet, ahol az egyes intézmények részéről felajánlott, ingyenesen kutatható tartalmak egy közös kutatói regisztrációval érhetők el. Ez a közös szolgáltatás 2015-ben kezdődött, az 1944-1945. évek egyházi halotti anyakönyveinek közlésével. ${ }^{5}$ A kutatható tartalom a jövőben várhatóan jelentősen bővülni fog (pl. a fent említett segédletekkel), továbbá a MELTE emellett az egyházi levéltárak

${ }^{4}$ Őskereső - A Magyarországi Evangélikus Egyház anyakönyvei, az interneten 1. http://www. oskereso.hu (2019. január 3.)

${ }^{5}$ „Az 1944-1945. évek egyházi halotti anyakönyvei. A polgári lakosság világháborús veszteségeinek nyomában.” A közös szolgáltatás hat levéltár együttmüködésével valósult meg, az interneten 1. https://matricula.hu (2019. január 3.) 
digitalizált tartalmainak áttekintésére - a teljes lista böngészésére és az elérhetőség adatainak közlésére, vagyis az átfogó tájékoztatásra - is lehetőséget kíván nyújtani honlapján. Az említett példák folytatásaként akár felekezeti, akár regionális alapon is elképzelhetők további csoportosulások (a kutatói igények ebbe az irányba mutatnak), és a szolgáltatások egyeztetése várhatóan a digitalizálás teljes folyamatára, illetve a feldolgozás egyéb fázisaira is hatással lesz. Összességében látható, hogy a hajózás kényszere mellé az együtt hajózás egyre erősödő igénye is társul: az előttünk álló feladatok magányos hajósként egyre kevésbé teljesíthetők.

\section{Rezümé}

Az utóbbi évtizedben több mint 6,3 millió digitális képfelvétel készült az egyházi levéltárakban örzött forrásokról. A képek segítségével az intézmények általában kutatói szolgáltatásokat is indítottak, melyek jelentősen megváltoztatták a levéltárak kutatóforgalmát. A tanulmány a digitalizálás folyamatát, a digitalizált iratok jellegét és a kutatói szolgáltatások tapasztalatait is vizsgálja egy körleveles felmérés válaszai alapján.

\section{Mass digitization in ecclesiastical archives - observations, and implications}

During the past decade more than 6.3 million digital photos were made of documents stored in ecclesiastical archives. Most of the institutions have started services for researchers on the bases of the pictures, and this led to a significant change in the number of researcher visits to the archives. On the bases of a questionnaire survey, the study investigates the process of digitization, the types of documents digitized, and the experiences regarding services to researchers.

LAKATOS ANDOR levéltárvezető Kalocsai Főegyházmegyei Levéltár 